\title{
MEDIA OF NATIONAL MINORITIES IN VOJVODINA
}

DOI: http://dx.doi.org/10.18509/GBP.2018.29

UDC: 323.15:316.774(497.113)

\section{Bojan Đerčan}

Tamara Lukić

Milka Bubalo-Živković

Department of geography, tourism and hotel management, Faculty of Sciences,

University of Novi Sad, Serbia

\begin{abstract}
Public information in the languages of national minorities is an important element of the media sector of each country, and especially of multiethnic, multi-confessional and multilingual countries that genuinely care for the ratified Council of Europe documents, such as the Framework Convention on the Protection of National Minorities and the Charter on Regional and Minority Languages, to be an active part of everyday life of a democratically established community. About a million members of various national minorities live in Serbia. Minority communities are mainly concentrated in the northern part of Serbia - Vojvodina (Hungarian, Slovakian, Romanian, Rusyn, etc.). There is a long tradition of informing in minority languages. Only in Vojvodina there are about 114 media that at least partially produced content in 11 minority languages. The rights of national minorities in the field of information are guaranteed by the Constitution, media laws, ratified international documents. However, informing minorities is still taking place today without a consistent media policy. It remains on legal confusion relating to the regulation of state property in the media in the languages of minorities, which is the result of political agreements within the ruling political elite.
\end{abstract}

Keywords: national minorities; minority languages; informing; Vojvodina.

\section{INTRODUCTION}

Respecting the media freedom and the independence of editorial policy, on one side, and the obligation to protect the right to information in the minority language, on the other, are reasons that the international community does not have generally accepted standards on how the right to information in the languages of national minorities should be exercised [1], [2], [3]. In the practice of the Republic of Serbia, all known models of information in the languages of national minorities are represented: public service programs, regular broadcasts, or articles in private media, the existence of minority printed and electronic media, as well as the use of the Internet, television without borders, access to the media of the countries of origin and so on.

The data of the national councils of national minorities and authorities show a high number of media with programs in the minority languages. In addition to a significant number of local public information companies included in a regular program scheme which had program in the languages of national minorities, increased interest of private broadcasters and productions to produce and broadcast content in the languages of national minorities started in 2004 when the competition was introduced as a way of co- 
financing in the field of information in the languages of national minorities at the republic and provincial level, but also in some local self-governments.

The reason why the issue of information in minority languages is constantly actual is that, apart from the right to be informed in their own language about all topics of interest to citizens, the production and broadcasting of cultural, educational, scientific, children's, film and other radio and television shows (audio-visual content) contributes to the preservation of cultural and linguistic identity and the development of the cultural creativity of the minority community. Meeting these needs of citizens contributes to their integration. In addition, subtitling the television program, i.e. translating into the Serbian language creates the possibility for citizens belonging to the majority or other minority communities to follow these programs, thus contributing to mutual understanding and tolerance. Consequently, the contents in the languages of national minorities, as well as the operation of minority media, contribute to program diversity and pluralism of the media as an important precondition for the development of a civil and democratic society. From the standpoint of the rights of members of national minorities, it is important that the Law on Public Information and the Media has regulated information in minority languages as a public interest that is realized in three equal ways through: forming public services, enabling national councils of national minorities to establish institutions and companies for the purpose of exercising the right to public information and co-financing projects through public information competition. In addition, the Law prescribes that public interest in the field of public information is, among other things, true, impartial, timely and complete informing in the native language of citizens of the Republic of Serbia belonging to national minorities and the preservation of the cultural identity of national minorities living in the territory of the Republic of Serbia.

\section{METHODS}

Vojvodina is one of the most ethnically diverse regions in Europe. In addition to the majority Serbian population, there are also twenty different ethnic groups in this area [4]. Informing in the languages of national minorities provides diversity and compatibility of contents which specifically supports the respect of human rights and respect for cultural, national, ethnic and political pluralism of ideas and opinions. Therefore, an inventory of the current state of the media space of Vojvodina in the languages of national minorities is made in the paper.

Based on data obtained from national councils of national minorities, which were collected during September and October 2017, an overview of the availability of public information media for members of national minorities was made. The data obtained from the national councils are thus systematized to give an insight into the number, periodicity and subject matter of printed media, as well as the number, type of broadcasters and the length of broadcasting programs in the languages of national minorities in electronic media. The review specifically apostrophes the broadcasters that are still state-owned: public service broadcasters, as broadcasters with special obligations prescribed by law. In addition, radio and television stations at local or regional level are analyzed.

\section{RESULTS AND DISCUSSION}

The Law on National Councils of National Minorities [5], inter alia, defines the competencies of national councils in the field of informing, as one of the four areas in 
which national minorities are institutionally self-governed. Provisions of articles 19-21 of this law describe that national councils can independently or jointly with other legal entities establish institutions and companies for conducting newspaper-publishing and radio-television activities, printing and reproduction of recorded media and exercising rights and obligations of founders. The founding rights over the public enterprises and institutions in the field of public information that fully or predominantly inform in the language of the national minority, whose founders are the Republic, an autonomous province or a local self-government unit, can be transferred in whole or in part to national councils.

Informing in the native language of members of the Hungarian national minority is realized through:

- 30 printed media, daily newspapers - Magyar Szó, Novi Sad; five weekly magazines - Új Kanizsai Újság, Kanjiža, Családi kör, Novi Sad, Temerini Újság, Temerin, Hét Nap, Subotica and Dunatáj, Sombor; five monthly magazines - Tordai Újság, Torda, Fecske, Feketić, Szó-Beszéd, Mali Iđoš, Csantavéri Újság, Čanatavir and Horgos Kisújság, Horgoš; five quarterly magazines - Muzslyai Újság, Mužlja, Kisoroszi Hirmondó, Rusko Selo, Csernyei Újság, Nova Crnja, Magyarittabéi Hírmondó, Novi Itebej and Kispiaci Hirmondó, Male Pijace; two multi-monthly magazines - Kisújság, Stara Moravica and Ludasi Hírharang, Ludoš; two children's magazines - Jó Pajtás, Novi Sad and Mézéskalács, Novi Sad; Youth Magazines - Képes Ifjúság, Novi Sad; nine magazines in the field of culture - Sikoly, Mužlja, Híd, Novi Sad, Létünk, Novi Sad, DNS, Novi Sad, Hungaloroška saopštenja, Novi Sad, Symposion, Subotica, Üzenet, Subotica, Bácsország, Subotica and Aracs, Subotica; four multilingual weekly magazines - Novi glas komune, Apatin, Bečejski mozaik, Bečej, Zrenjanin, Zrenjanin and Kikindske, Kikinda; five multilingual monthly newspapers - Moj Kovin (Igaz Szó), Kovin, Čokanski hronika, Čoka, Opštinska panorama, Ada, Kulska komuna, Kula and Novokneževačke novine, Novi Kneževac; multilingual multimonthly magazines - Ogledalo, Novo Orahovo; 4 multilingual magazines in the field of culture - Magazin pod vulkanom, Senta, Oglinda, Sečanj, Regional, Subotica and Karton, Subotica;

- programs at 26 radio stations, regional public broadcasting service - Radio Novi Sad (24 hours per day); 13 radio stations of local communities - Radio Subotica (14 hours per day), Radio of the Region, Bačka Topola (6 hours per day), Radio Bela Crkva (1 hour per week), Radio Vrbas (6 hours per week), Radio Zrenjanin (1 hour per day) Radio Kikinda (6.5 hours per week), Radio Kovačica (1 hour per day), Radio Novi Bečej (18 hours per week), Radio Odžaci (2 hours per week), Radio Sečanj (1 hour per week), Radio Kulska komuna (1.5 hours per day), Radio Temerin (5 hours per day), and Radio Bačka, Bač (1 hour per week); 12 radio stations of other types of broadcasters - Pannon radio, Novi Sad (24 hours a day), Radio Ada (12 hours per day), Radio Trend, Bačka Topola (0.5 hours per day), Radio Active, Bečej (4 hours per day), Panda radio, Kanjiža (17 hours per day), Radio Bus, Kovin (1.5 hours per week), Yu Eco radio, Subotica (2 hours per day), Radio Sombor (2 hours per day), Radio Srbobran (30 hours per week), Radio Max , Čoka (4 hours per day), No Limit, Senta (1 hour per week) and Radio Marija Subotica (6 hours per day);

- programs at eight TV stations, provincial public broadcasting service - Television of Vojvodina (64 hours per month); three local community TV stations - OK TV, Kovačica ( 0.5 hours per day), TV Pančevo ( 0.5 hours per week) and Novosadska TV (7.5 hours per month); four TV stations of other types of broadcasters - TV Mozaik, 
Novi Sad (12 hours per day); TV Kanal 25, Odžaci (0.5 hours per week), YU ECO TV, Subotica (2 hours per day) and Pannon TV, Subotica (6 hours per day) [6].

- Informing in the native language of members of the Roma national minority is realized through:

- two printed media, magazines in the field of culture - Romologija, Deronje; bilingual monthly magazines - Romano Nevipe, Belgrade;

- program at 11 radio stations, two public broadcasting services (republic and provincial), - Radio Belgrade (0.5 hours per day) and Radio Novi Sad (1 hour per day); five radio stations of local communities - Radio Bela Crkva (1 hour per week), Radio Kikinda (4 hours per week), Radio Novi Bečej (1 hour per week), Radio Odžaci (2 hours per week), Radio Zrenjanin (16 hours per month); 4 radio stations of other types of broadcasters - Radio Bus, Kovin (1 hour per month), Radio Blue, Odžaci (0.5 hours per week), Radio Sombor (1.5 hours per day), Radio Srbobran (1 hour per week);

- programs at 2 TV stations, provincial public broadcasting service - Television of Vojvodina (58 hours per month); one TV station of local communities - TV Pančevo (0.5 hours per week) [7].

Informing in the native language of members of the Romanian national minority is realized through:

- 16 printed media, weekly newspapers - Libertate, Pančevo; one monthly magazine Kuvntul romanesk, Vršac; quarterly magazine - Strazerul, Straža; 2 multi-monthly magazines - Familia, Vladimirovac; children's magazines - Bucuria Copilor, Pančevo; Youth Magazine - Tineretea, Pančevo; six magazines in the field of culture - Lumina, Pančevo, Limba Romana, Vršac, Traditia, Novi Sad, Tibiscus, Uzdin, Europa, Novi Sad, Floare de latinitate, Novi Sad and Thesaurus romanesk, Pančevo; three multilingual monthly magazines - Vršačka Kula, Vršac, Zrenjanin, Zrenjanin and Opštinski bilten, Alibunar and multilingual magazine in the field of culture Oglinda, Sečanj;

- programs at 10 radio stations, regional public broadcasting service - Radio Novi Sad ( 5 hours per day); 5 radio stations of local communities - Radio Bela Crkva (1 hour per week), Radio Zrenjanin (1.5 hours per week), Radio Kikinda (2 hours per week), Radio Kovačica (2.5 hours per day) and Radio Sečanj (1 hour per week); four radio stations of other types of broadcasters - Radio Far, Alibunar (4 hours per day), Radio Bus, Kovin (1 hour per week), Radio Santos, Zrenjanin (1 hour per week) and Radio Viktorija, Vršac (24 hours a day);

- programs at $6 \mathrm{TV}$ stations, provincial public broadcasting service - Television of Vojvodina (58 hours per month); two local communities - OK TV, Kovačica (2.5 hours per day) and TV Pančevo (1 hour per week); three other types of broadcasters TV Viktorija, Vršac (12 hours per day), TV Santos, Zrenjanin (0.5 hours per week) and TV Banat, Vršac (0.5 hours per week) [8].

- Informing in the native language of members of the Rusyn national minority is realized through:

- seven printed media, weekly newspapers - Ruske slovo, Novi Sad; monthly magazines - Dzvoni, Ruski Krstur; multi-monthly magazine Kalendar, Novi Sad; children's magazine - Zagradka, Novi Sad; Youth magazine - Mak, Novi Sad; two magazines in the field of culture - Švetlosc, Novi Sad, Studia Rutenika, Novi Sad; multilingual monthly magazine - Kulska komuna, Kula; multilingual monthly magazine - Glas 
Sojuzu, Novi Sad and multilingual magazine in the field of culture - Erato nad Kucurom, Novi Sad;

- programs at eight radio stations, regional public broadcasting service - Radio Novi Sad (5 hours per day); 4 radio stations of local communities - Radio of the Region, Bačka Topola (0.5 hours per week), Radio Vrbas (1 hour per day), Radio Šid (0.5 hours per week) and Radio Kulska komuna (1.5 hours per day); three radio stations of other types of broadcasters - Radio Trend, Bačka Topola (1 hour per week), Radio Blue, Odžaci (0,5 per week) and Radio Blue Plus and Odžaci (0,5 hours per week);

- programs at $3 \mathrm{TV}$ stations, provincial public broadcasting service - Television of Vojvodina (58 hours per month); one TV station of the local community - TV Bačka, Vrbas (1 hour per month); one TV station of other types of broadcasters - TV Kanal 25, Odžaci (0.5 hours per week) [9].

Information in the native language of members of the Slovakian national minority is achieved through:

- 16 printed media, weekly newspapers - Hlas L'udu, Novi Sad; two monthly newspapers - Petrovske novine, Bački Petrovac, Evangeliski hlasnik, Novi Sad; three quarterly magazines - Novi rod, Bački Petrovac, Večni život, Bački Petrovac and Padinske zvoni, Padina; three quarterly magazines - Evanjelička ročenka, Novi Sad, Narodni kalendar, Bački Petrovac and Pazovski Kalendar, Stara Pazova; children's magazine - Zornička, Novi Sad; Youth magazine - Vzlet, Novi Sad; five magazines in the field of culture - Novi život, Bački Petrovac, Majak, Novi Sad, Obzori, Novi Sad, Traf, Novi Sad and Aurora, Stara Pazova; two multilingual weekly magazines Zrenjanin, Zrenjanin and Nedeljne novine, Bačka Palanka and multilingual monthly magazine - Pazovačka revija, Stara Pazova;

- programs at 14 radio stations, regional public broadcasting service - Radio Novi Sad (5 hours per day); nine radio stations of local communities - Radio Bačka, Bač (5 hours per week), Radio Zrenjanin (1.5 hours per week), Radio Kovačica (6 hours per day), Radio Odžaci (2 hours per week), Radio Stara Pazova (5 hours per day), Radio Šid (1 hour per week), Radio Petrovac, Bački Petrovac (24 hours a day), Radio Kisač, Novi Sad (51 hours per week) and Radio Beočin (0.5 hours per week); four radio stations of other types of broadcasters - Radio Far, Alibunar (1 hour a day), Radio Trend, Bačka Topola (1 hour a week), Radio Blue, Odžaci ( 0.5 hours per week) and Radio Blue Plus, Odžaci (0.5 hours per week);

- programs at nine TV stations - Provincial Public Broadcasting Service - Television of Vojvodina (58 hours per month); five TV stations of local communities - OK TV, Kovačica (2 hours per day), TV Pančevo (0,5 hours per week), TV Bap, Bačka Palanka (0,5 hours per week), Novi Sad TV ( 8 hours per month) and TV Stara Pazova (1 hour per day); three TV stations of other types of broadcasters - TV Petrovac, Bački Petrovac (24 hours a day), Sremska TV, Šid (0.5 hours per week) and TV Kanal 25, Odžaci ( 0,5 hours per week).

Information in the native language of members of the Ukrainian national minority is realized through:

- 5 printed media, monthly newspapers - Ridne slovo, Kula; children's magazine Solovejko, Novi Sad; three magazines in the field of culture - Slovo, Novi Sad Ukrajinske slovo, Novi Sad and Kalendar, Novi Sad;

- programs at four radio stations, regional public broadcasting service - Radio Novi Sad (6 hours per week); three radio stations of the local community - Radio Vrbas (1 hour 
per week), Radio Inđija (1 hour per week) and Radio Kulska komuna (1.5 hours per week);

- programs at one TV station, provincial public broadcasting service - Television of Vojvodina (0.5 hours per week) [10].

- Informing in the native language of members of the Croatian national minority is realized through:

- 15 printed media: weekly newspapers - Hrvatska riječ, Subotica; three monthly magazines - Glas Ravnice, Subotica, Zvonik, Subotica, Glasnik Pučke kasine, Subotica; quarterly magazines - Miroljub, Sombor; five multi-monthly magazines Otac Gerard, Sombor, Glas Šokadije, Sonta, Hrvatski Majur, Subotica, Gupčeva lipa, Tavankut and Hosana, Stari Žednik; children's magazines - Hrcko, Subotica; Youth Magazine - Kužišs?!, Subotica; three journals in the field of culture - Godišnjak za znanstvena istraživanja, Subotica, Klasje naših dana, Subotica and Subotička Danica, Subotica; multilingual weekly magazine - Glas Komune, Apatin; two multilingual magazines in the field of culture - Regional, Subotica and Karton, Subotica;

- programs at four radio stations, three radio stations of the local community - Radio Subotica (3 hours per day), Radio Bačka, Bač (0.5 hours per week), Radio Odžaci ( 0.5 hours per week); one radio station of other types of broadcasters - Radio Sombor (1 hour per week);

- programs at two TV stations, provincial public broadcasting service - Television of Vojvodina (10 hours per month); one TV station of other types of broadcasters - TV Spektar, Sombor (0.5 hours per week) [11].

Public Broadcasting Service Radio-Television of Vojvodina has a special responsibility to broadcast programs in minority languages since a significant percentage of the AP Vojvodina population is represented by national minorities. According to data obtained from this public broadcasting service, Radio Novi Sad broadcasts a program in nine languages of national minorities. Television of Vojvodina broadcasts a program in nine languages of national minorities, every day in Hungarian, Roma, Romanian, Rusyn, Slovakian and Croatian, and once a week in Bunjevac, Macedonian and Ukrainian language .

There are many different sections of the RTV television program in Hungarian, Slovakian, Romanian, Rusyn, Roma, Croatian, which is broadcasted daily or in a regular program scheme. Magazine-type TV shows are broadcasted in Ukrainian, Macedonian and Bunjevac languages, premiered once a week, as well as a broadcast of independent production in the Montenegrin language. In addition, RTV also broadcasts the "Paleta" show every working day, in the form of content selection from shows that are broadcasted in the original languages of national minorities with the subtitle in Serbian. It allows all citizens to get acquainted with and learn about themes that are broadcasted in the Second Program of RTV, and therefore with life, problems and manifestations of ordinary people, neighbors, while languages of communities in their original form are also heard in the program. The "Paleta" is broadcasted in Hungarian, Slovakian, Romanian, Rusyn, Roma, Croatian, Bunjevac, Ukrainian and Macedonian, and each of these individual shows has its established term and broadcasting rhythm. In order to avoid individual show listing, the table shows the structure of the entire broadcasted programs in the languages of national minorities on the Second Program of TV RTV, a semiannual cross section, in the period from January 1, 2017 to June 30, 2017 [12]. 
Table 1. Structure of the entire broadcasted program in the languages of national minorities on the Second Program of RTV [12]

\begin{tabular}{lll}
\hline Language & Broadcasted minutes & Percentage share in the program \\
Hungarian & 55.279 & $21.10 \%$ \\
\hline Serbian & 53.762 & $20.52 \%$ \\
Other languages (non-program) & 25.989 & $9.92 \%$ \\
\hline Minority language/Serb subtitle & 22.867 & $8.73 \%$ \\
\hline Roma & 18.434 & $7.04 \%$ \\
\hline Rusyin & 17.833 & $6.81 \%$ \\
\hline Music shows & 17.776 & $6.79 \%$ \\
\hline Slovakian & 17.667 & $6.74 \%$ \\
\hline Romanian & 16.339 & $6.24 \%$ \\
\hline Croatian & 7.894 & $3.01 \%$ \\
\hline Ukrainian & 2.991 & $1.14 \%$ \\
\hline Bunjevac & 2.865 & $1.09 \%$ \\
\hline Macedonian & 2.196 & $0.84 \%$ \\
\hline Languages of other minorities and & 93 & $0.04 \%$ \\
Serbian subtitle & & $\mathbf{1 0 0 \%}$ \\
\hline Total & $\mathbf{2 6 1 . 9 8 5}$ & \\
\hline
\end{tabular}

The same is the case with the radio program, given that the Second Radio Program of RTV broadcasts a twenty-four-hour program in the Hungarian language, while the Third Radio Program, with a great variety of media contents, produces and broadcasts 1,440 minutes of programs in minority languages on a daily basis. At the annual level, this amounts to 527,160 minutes of programs in the Slovakian, Romanian, Rusyn, Ukrainian, Roma, Croatian, Bunjevac, Macedonian and Montenegrin languages. Such RTV standards are very high in comparison with public services of other countries.

\section{CONCLUSION}

Starting from the Constitutional obligation by which the Republic of Serbia guarantees to persons belonging to national minorities the right to information in their own language in order to preserve the national, cultural and linguistic identity and full equality of national minorities, minority media in Vojvodina exist as commercial, as the media of civil society and as the media of national councils of national minorities. National Councils of National Minorities may be founders of public media in the language of the national minority for which they are established and these public media have editorial independence in accordance with the law.

Statistically observed in Vojvodina, the right of national minorities to information in their own language is fully fulfilled. Newspapers come out regularly and multi-hourly daily/weekly radio and TV programs are broadcasted in as many as 10 languages (Hungarian, Slovakian, Romanian, Rusyn, Ukrainian, Roma, Croatian, Bunjevac and occasionally German and Macedonian). In addition to provincial, regional and local printed and electronic media, a multilingual program is also broadcasted by Broadcasting Institution of Vojvodina as a public service founded by citizens, financed by citizens and controlled by citizens. The most broadcast hours are in Hungarian, and the least in German, that is, in Bunjevac and Macedonian, which corresponds to the shares of speakers of these languages in the total population of Vojvodina. 


\section{REFERENCES}

[1] Klimkiewicz, B. Media Policy for Ethnic and National Minorities in Poland, the Czech Republic and Slovakia, in: Sükösd, M. \& Bajomi-Lázár, P. (Eds.): Reinventing Media, Media Policy Reform in East-Central Europe, Central European University Press, pp. 155-184, 2003.

[2] Mahtani, M. Representing Minorities: Canadian Media and Minority Identities, Canadian Ethnic Studies, Vol. 33, Issue 3, pp. 99-133, 2001.

[3] Camauër, L. Ethnic Minorities and their Media in Sweden, Nordicom Review, Vol. 24, Issue 2, pp. 69-88, 2017.

[4] Statistical Office of the Republic of Serbia, Ethnicity. Data by municipalities and cities, The Census of population, households and dwellings, Book 1, Belgrade, 2012.

[5] Law on National Councils of National Minorities, Official Gazette of the Republic of Serbia, No. 72/2009, 20/2014 - decision US i 55/2014.

[6] National Council of the Hungarian National Minority http://archiv.mnt.org.rs/sr

[7] National Council of the Roma National Minority http://www.romskinacionalnisavet.org.rs/

[8] National Council of the Romanian National Minority http://www.cnr.rs/

[9] National Council of the Rusyn National Minority http://www.rusini.rs/sr

[10] National Council of the Slovak National Minority, http://www.rada.org.rs/sr

[11] National Council of the Croatian National Minority http://www.hnv.org.rs/

[12] Public Broadcasting Service of Vojvodina http://rtv.rs/sr_ci/about-us 